\title{
Micro Hydro Potential Modelling: Integrating GIS into Energy Alternatives for Climate Change Mitigation
}

\author{
Gerald C. K. Chelelgo'1, David N. Siriba'2, Elijah K. Biamah' ${ }^{1}$ \\ ${ }^{1}$ Department of Environmental and Biosystems Engineering, University of Nairobi, Nairobi, Kenya \\ ${ }^{2}$ Department of Geospatial and Space Technology, University of Nairobi, Nairobi, Kenya \\ Email: gerald.cheruiyot@gmail.com
}

Received 1 June 2016; accepted 21 August 2016; published 25 August 2016

Copyright (C) 2016 by authors and Scientific Research Publishing Inc.

This work is licensed under the Creative Commons Attribution International License (CC BY). http://creativecommons.org/licenses/by/4.0/

(c) (i) Open Access

\section{Abstract}

This research focused on integrating GIS into energy alternatives for climate change mitigation by creating a GIS-based hydrologic model that can be used to identify sites that have significant potential for micro hydropower development within the River Perkerra catchment area. Hydropower is a clean and renewable energy source that remains largely untapped in the country and its development can be used to mitigate anthropogenic climate change by reducing reliance on fossil or biomass derived fuels. This research established the extent of this resource and whether the available sites with significant micro hydropower potential within the study area were amply copious to warrant further development. Currently, such identification is done physically using means that are menial, costly and significantly time consuming. A 90-metre resolution Digital Terrain Model (DTM) data obtained from the Shuttle Radar Topography Mission and various GIS tools were used to create a hydrologic framework which was used to identify potential sites along River Perkerra that suited any desired head requirement for the purposes of locating micro hydropower plants. The derived model demonstrated that it was possible to identify sites at discrete geographic locations along any stream drainage network using GIS. In addition, the model also provides a decision support system that integrates a powerful graphical user interface, spatial database management system and a generalized river basin network flow model for the purposes of exploiting and developing micro hydropower. With sufficient data on catchment discharge and use of higher resolution DTM, the model can be further enhanced to accurately obtain the total microhydro potential of River Perkerra by aggregating the respective potentials of every steam segment.

\section{Keywords}

Component, Formatting, Style, Styling, GIS, Micro Hydropower Modelling, DTM, Catchment 


\section{Delineation, River Perkerra}

\section{Introduction}

Kenya hopes to industrialize by 2030 [1]. This would involve development of industries on an extensive scale and impact on the livelihood of its citizens. Industrialization has both negative and positive impacts. The positive impacts include economic growth and food security among others, whereas the negative impacts include climate change which was first noticed as an impact of industrialization by Svante Arrhenious, a 19th century Swede scientist [2]. The development agenda of many developing countries are increasingly being affected by climate related disasters including hurricanes, drought, floods and landslides [3], largely because of the increasing climate variability and the risk associated with it [4].

Climate variability is already having a large negative effect on the region's socio-economic development. This is likely to worsen with climate change hence the need to vigorously pursue adaptation to climate change. Together with other factors including rapidly growing population, poor management of natural resources and limited use of technologies, climate variability or long-term climate change could worsen the poverty situation in Kenya. Due to the many and diverse impacts likely to result from climate change, a combination of mechanisms including both technical and social strategies would be needed to promote adaptation [5].

The causes of climate change are related to energy use and as such, it has been established that anthropogenic factors mainly resulting from greenhouse gas emissions associated with energy use and generation are the key causes of climate change. Currently, $\mathrm{CO}_{2}$ concentrations stand at $380 \mathrm{ppm}$ and the global average temperature has risen by $0.6^{\circ} \mathrm{C}$ over the past 100 years with related impacts being observed. With status quo prevailing, continued use of fossil fuels and destruction of bio-mass to satisfy the ever growing energy demand, the global average temperature is expected to rise by between $1.4^{\circ} \mathrm{C}$ and $5.8^{\circ} \mathrm{C}$ this century [6].

Energy is indeed necessary for economic development and the level or intensity of its use is synonymous to any country's economic growth and development. Countries with low per capita consumption of commercial energy would typically have correspondingly low per capita Gross Domestic Product (GDP) [1]. This is true for Kenya whose commercial energy consumption has declined over the previous three decades when the economy has had a weak performance and growth. Countries that have achieved strong growth such as Egypt, South Africa and the Asian tiger economies have equally had a similar increased trend in energy consumption and Gross National Income (GNI) [7].

Since factors related to energy use are the main contributors to climate variability, any technical intervention needs to focus more on greener sources of energy. Some of these green energy sources include the solar, geothermal, and hydro-power. These are already being used in the Kenya but siting of the points for harnessing energy including hydropower has been a challenge. This research aimed at providing a means of identifying potential micro hydropower sites using GIS to enable further evaluation and development to harness this clean energy source.

Climate change is an issue of global impact and concern which is driven mainly by anthropogenic causes. There is need to adopt cleaner energy and at the same time reduce demand for biomass energy that has driven destruction of forests which naturally act as carbon banks whilst sequestering atmospheric carbon dioxide, one of the major greenhouse gases [8]. Hydropower is one of the most common renewable energy resources abundantly available in regions that receive significant rainfall and provides itself as an alternative clean, low cost and well developed technology that can be adopted to avert energy scarcity, biomass destruction and advancement of climate change [9]. Likewise in Kenya, there is an estimated 3000 MW of untapped hydroelectric capacity of small, micro to pico hydropower, part of which may be viable for community based electricity production, detailed resource assessments have only been done for a small number of hydroelectric power projects in all regions making it impossible for hydroelectric power projects to be included in the least-cost power development plan [10].

Considering that Geographic Information System (GIS) technology is evolving, its use is expected to steadily increase across a multitude of domains as it provides an efficient framework for geo-referencing information enabling expedited and accurate decision making based on location and innate relationships hence reducing the costs associated with extensive fieldwork and manual office work. 
The overall problem addressed by this study is that while the use of GIS has been commonplace in disciplines such as forestry, hydrology, environmental management, geology and mining, it has not been used extensively in the exploitation of renewable energy sources. Currently, identification of suitable micro hydropower sites within river drainage networks is conducted through abstract and manual means that do not provide the entirety of crucial hydrological information needed to support decision making. This process is menial, time consuming and costly hence in order to hasten and improve the process of locating and planning micro hydropower projects within a given river basin there are pertinent research questions such as: Could GIS be used as a proactive planning tool that could lay ground for a quicker assessment of micro hydropower potential and identification of suitable sites where this source of renewable energy can be effectively exploited? The objective of this research study was to identify sites along the gauged stream segments within River Perkerra catchment area in Baringo County, Kenya with significant potential for micro hydropower development and subsequently estimate the electric power generation potential.

\section{Hydropower Modelling}

Hydropower has been in use since ancient times from before 200 B.C. by the Greeks and Chinese where this form of energy was harnessed for basic tasks such as irrigation, grinding of grains into flour [11]-[13]. In terms of significance, hydropower is amongst the key sources of renewable energy for electrical power production with a projected global potential of 14,370 TWh/year, of which $8080 \mathrm{TWh} / \mathrm{yr}$. is currently considered economically viable [14]. Consequently rural populations in Africa including those located far away from the electricity distribution grid can hugely benefit from local small-scale hydropower projects [15].

Electricity is a secondary energy source, obtained through conversion of primary sources of energy such as hydropower, thermal, wind or solar [16] as such; micro hydropower generation is an inexpensive compliment to solar and other renewable energy forms. The nature of hydropower makes its use possible beyond a single home and instead can provide electric power to a several homes. Apart from being environmentally benign, having a long running life and maintenance easy, small-hydro has the advantage of being amongst cost-effective energy technologies that can be considered for rural electrification in developing countries while also augmenting power generation from large hydro schemes Whereas reservoirs associated with large-hydro have considerable social and environmental impacts such as interrupted fish breeding, methane release into the atmosphere, water quality degradation, intensification of disease vector as well as reduced water availability downstream, small hydro is a cleaner substitute [17] [18]. Another benefit of micro hydropower is that water, which would otherwise cause soil loss on steep slopes, is directed through pipes and its force is used to produce energy rather than cause erosion.

To date, there is still no internationally agreed definition of small-hydro. Some school of thought applies the term small-hydro to collectively cover small, mini, micro and pico hydropower schemes. Conventionally, smallhydro refers to between 2.5 and $25 \mathrm{MW}$, mini-hydro typically refers to schemes below $2 \mathrm{MW}$, micro-hydro below $500 \mathrm{~kW}$ and pico-hydro below $10 \mathrm{~kW}$. These are arbitrary demarcations though most principals cut across smaller and larger schemes [19]. Pepermans and others define small-hydro as ranging between $1-100 \mathrm{MW}$ and micro-hydro between $25 \mathrm{~kW}-1 \mathrm{MW}$. Some authors define generation between $1 \mathrm{~kW}$ and $1 \mathrm{MW}$ as dispersed generation [20].

While the process of identifying potential micro hydropower sites can be an overwhelming exercise, remote sensing and GIS technology can play a pivotal role in the scientific assessment of drainage networks to accurately identify locations with the highest potential for hydropower development hence increasing access to affordable energy [21]. Hydropower potential is directly related to the geography of an area, amount of precipitation and soil saturation. GIS can be used to evaluate specific watersheds for runoff and the difference in elevation from where water can be collected and where a turbine can be located. Rojanamon et al. propose new methods of application of GIS to site selection of small run-of-river hydropower that can help address some of the challenges encountered during site selection of small run-of-river hydropower projects occasioned by accessibility of the possible sites which are mostly located in rural and mountainous areas, the large amount of data required, and the lack of participation of the local communities [22].

Das, S. \& Paul, P. K. note the difficulty of site selection for small hydro in the inaccessible tracts of Himalayan region while using conventional methods leading to considerable loss of time and money. Their research demonstrated the use GIS and Remote Sensing technology to arrive at various alternative sites available in the 
study area and finally to select the most technically suitable site [23].

A study by Jha, R. used the hydro-meteorological data from Department of Hydrology and Meteorology for hydrological analysis of all the rivers in Nepal. By incorporating hydrological analysis, GIS and a purposely developed hydropower model as shown on Figure 1, the power potential and annual run-of-the-river energy estimate for the entire country was established [24].

A paper by Feizizadeh \& Haslauer [25] discusses the application of a GIS to calculate the theoretical surface hydropower potential of the Tabriz basin in Iran. GIS based hydrological modelling is performed on equi-areal raster cells using topographical and meteorological datasets. The input data was com-piled and analyzed using GIS data layers, including topographic characteristics, monthly evaporation and precipitation data to identify areas of the river network the highest potentials that could be used to locate for hydropower plant. Figure 2 illustrates the schema of the model used. From the above, GIS thus provides a practical means of modelling both elevation and hydrologic data.

This research proposes to adopt both models by Jha, R. [24] and Feizizadeh \& Haslauer [25] to create an enhanced one capable of identifying focus areas for development of micro hydropower hence facilitating development and increased use of electricity and mechanical energy derived from micro hydropower with an aim of: 1) reducing the use unsustainable energy sources and 2) reducing emissions generated by use of fossil fuels and biomass.

\section{Materials and Methods}

\subsection{Hydrologic Analysis}

Hydrologic Analysis was carried to obtain the respective flow duration curves at gauging station points along the Perkerra River. The flow duration curves were necessary for calculations to determine the average flow magnitude in a year that could be expected to be equal or exceed 40, 50 and 60 percentile of the time. The exercise involved use of primary data containing river flows from gauging stations supplied by the Water Resource Management Authority (WRMA) and the Rift Valley Water Services Board.

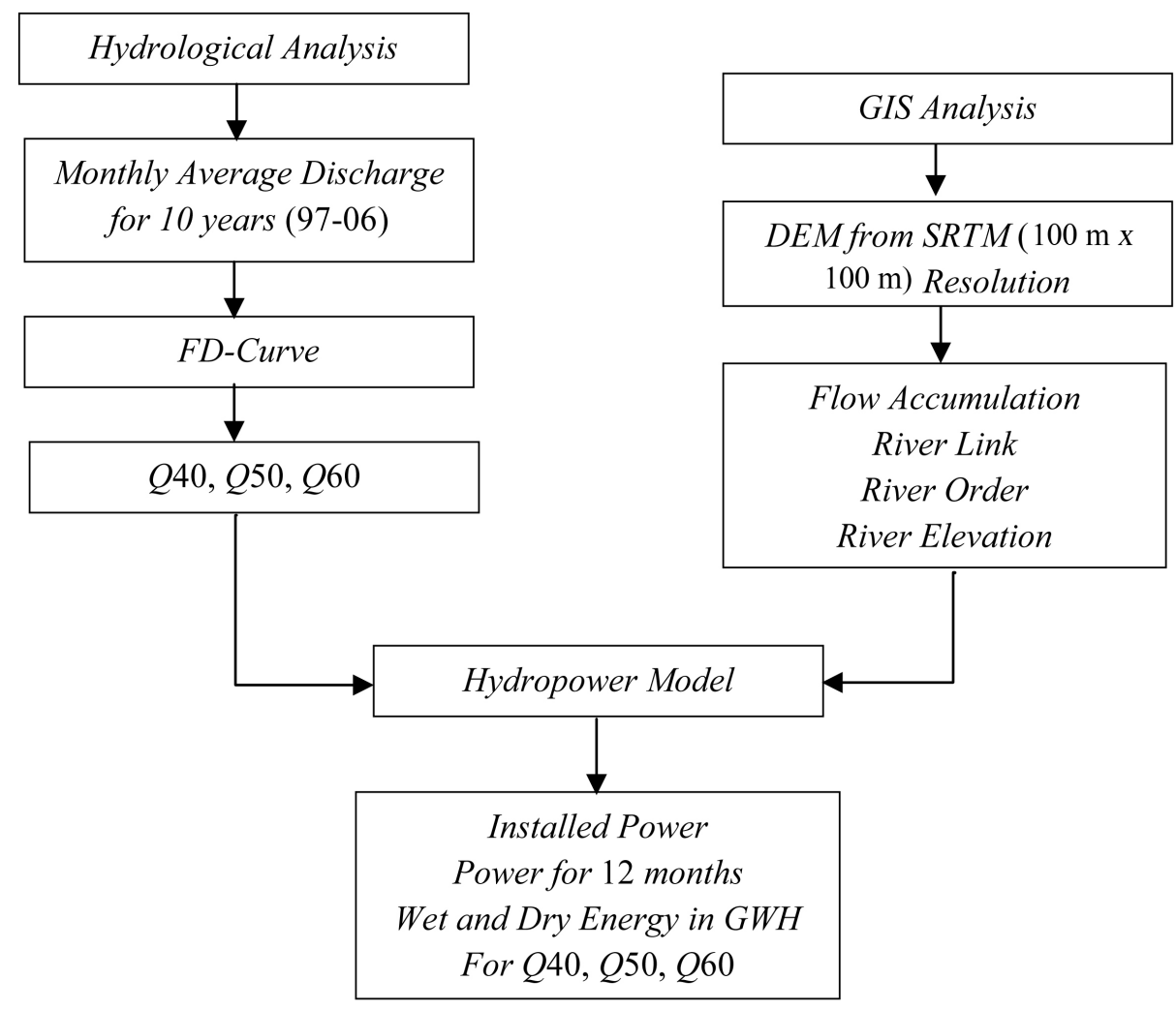

Figure 1. Model used to calculate the total run-of-river type hydropower potential of Nepal [24]. 

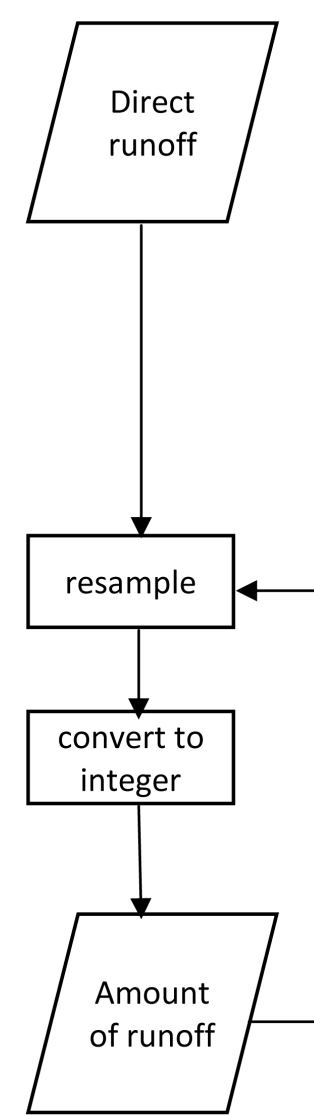

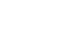
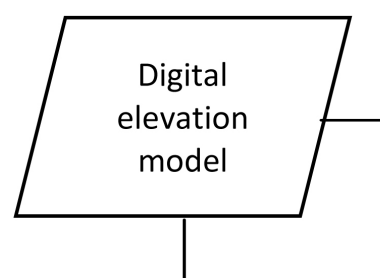


\subsection{Stream \& River Network Delineation}

Delineation of River Perkerra drainage network through GIS hydrologic modelling was done using ArcGIS Model Builder \& ArcHydro tools to process DEM data from the Shuttle Radar Topography Mission (SRTM) containing elevation data at a 90 m resolution in ASCII format. Ground truthing and topographic maps from the Survey of Kenya were used to validate the derived river network.

\subsection{Hydropower Modelling}

A hydropower model was developed by further processing the delineated drainage network of River Perkerra within ArcGIS to:

1) Identify sites along delineated stream network that have suitable head requirement for the purposes of locating micro hydropower plants.

a) Drop points within the area of interest were obtained by subtracting minimum neighbours from the area of interest DEM. The minimum neighbours were derived by applying 3 by 3 cell focal statistics against each pixel on the area of interest DEM.

b) Drop points along the river network were obtained through extracting by mask, drop points within the area of interest from a 3D raster representation of the river network. The river drop was colour coded and classified in terms of head as either high $(>50 \mathrm{~m})$, medium $(10-50 \mathrm{~m})$ or low $(<10 \mathrm{~m})$ which would guide the type of turbine as illustrated on Figure 3.

2) Identify potential hydropower sites along gauged stream segments within the study area.

a) To establish the hydropower potential, the river drop was multiplied by gravitational acceleration 9.81 ms-2.

b) The product of hydropower potential and river discharge would yield the extractable hydropower output of any identified site.

3) Estimate the power potential of selected hydropower sites along the gauged stream segments in the drainage basin. Using hydropower potential and discharge calculation from hydrologic analysis of the Perkerra River, the extractable Q40, Q50 \& Q60 hydropower output potential was obtained for high head sites along the Tigeri, Lelgel and Eldama Ravine gauged sections of the River Perkerra. A high-level flow chart of the model is shown in Figure 4.

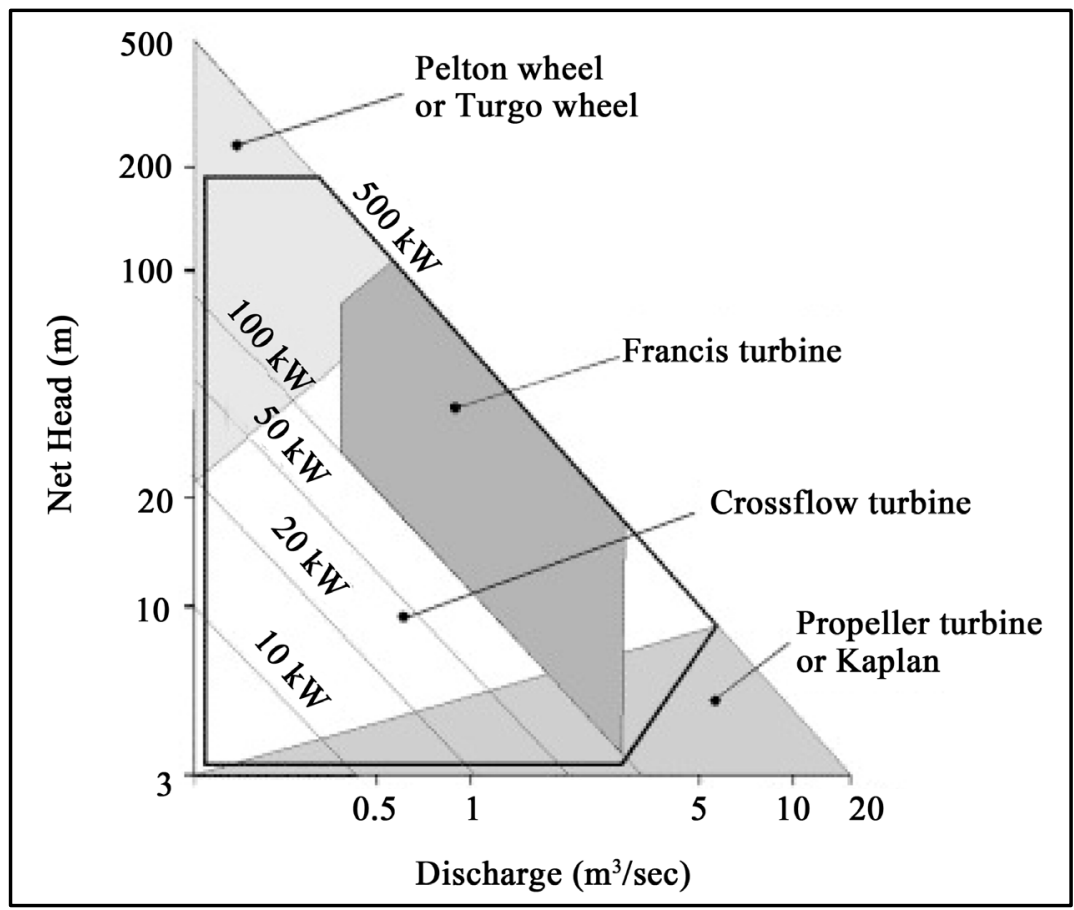

Figure 3. Turbine sizing [19]. 


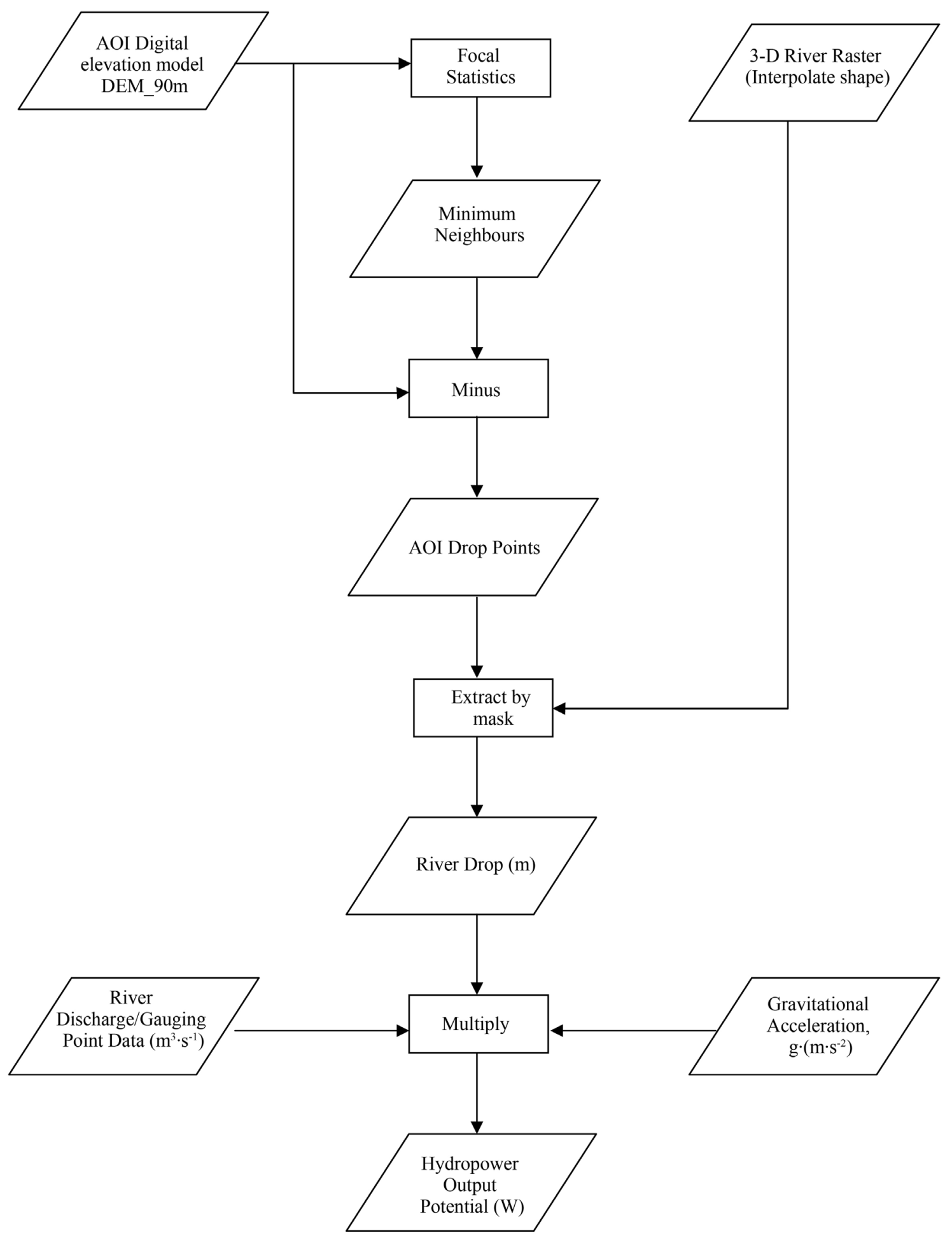

Figure 4. Hydropower potential model.

\section{Results and Analysis}

\subsection{Derived Flow Duration and Discharge}

For each gauging station with data flow-duration curves were derived with the cumulative frequency curve that 
showed the percent of time specified discharges were equaled or exceeded over the period which readings were recorded. The flow-duration curve represents the long-term characteristics of the gauged stream segments hence were used to predict the distribution of future flows for hydropower estimation. The respective Q40, Q50 and Q60 are tabulated on Table 1 below while Figure 5 and Figure 6 show the flow duration curves for the Tigeri gauging station 2ED01.

\subsection{Delineated Stream \& River Network}

The River Perkerra watershed and its stream network were delineated the from digital elevation model data. Figure 7 illustrates the 3D TIN surface rendering of the resultant river network. The derived stream network compared well to those obtained from digitized maps as shown an overlay with a stream network obtained from DEPHA in Figure 8. Digitized maps carry a bigger approximation due to the scale of representation being lower that the SRTM data used in this research explaining the few differences observed.

In addition, the GPS coordinates for gauging station obtained during site visits all fell within the derived river network confirming accuracy of the model. Figure 9 shows the relative positions of the gauging stations with

Table 1. Q40, Q50 and Q60 discharge values by gauging station.

\begin{tabular}{cccccc}
\hline $\begin{array}{c}\text { Gauging } \\
\text { Station Code }\end{array}$ & Name & Location & $\begin{array}{c}\text { Q40 } \\
\mathbf{m}^{\mathbf{3}} \cdot \mathbf{s}^{-\mathbf{1}}\end{array}$ & $\begin{array}{c}\mathbf{Q 5 0} \\
\mathbf{m}^{3} \cdot \mathbf{s}^{-\mathbf{1}}\end{array}$ & $\begin{array}{c}\text { Q60 } \\
\mathbf{m}^{3} \cdot \mathbf{s}^{-\mathbf{1}}\end{array}$ \\
\hline 2EB01 & WASEGES & KISANANA & 0.37 & 0.34 & 0.31 \\
2EC02 & RONGAI & RONGAI & 0.111 & 0.078 & 0.056 \\
2EC03 & RONGAI & RONGAI & 0.093 & 0.062 & 0.045 \\
2EC04 & RONGAI & RONGAI & 0.02 & 0.02 & 0.019 \\
2ED01 & TIGERI & KAPCHOLOI & 0.82 & 0.8 & 0.8 \\
2ED02 & LELGEL & POROR & 0.35 & 0.30 & 0.28 \\
2ED03 & ELDAMA RAVINE & ELDAMA RAVINE & 0.0 .30 & 0.28 & 0.24 \\
2EE07 & PERKERRA & KIMOSE & 2.718 & 1.7515 & 1.187 \\
2EE07A & PERKERRA & MARIGAT BRIDGE & 6.612 & 5.766 & 4.788 \\
2EE07B & PERKERRA & MARIGAT BRIDGE & 0.907 & 0.687 & 0.525 \\
2EE08 & PERKERRA & KIMNGOROM & 1.589 & 1.2 & 0.91 \\
2EF04 & NAROSURA & KABIMOI & 0.907 & 0.687 & 0.525 \\
2EG01 & MOLO RIVER & KELELWA & 0.863 & 0.575 & 0.404 \\
\hline
\end{tabular}

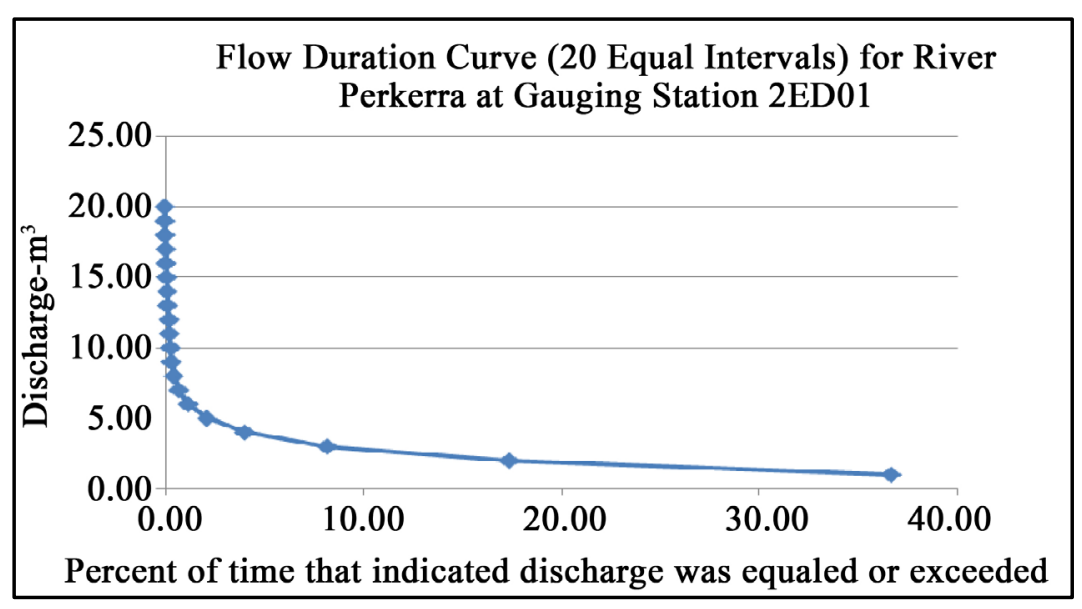

Figure 5. Flow duration curve (20 equal intervals) for River Perkerra at gauging station. 


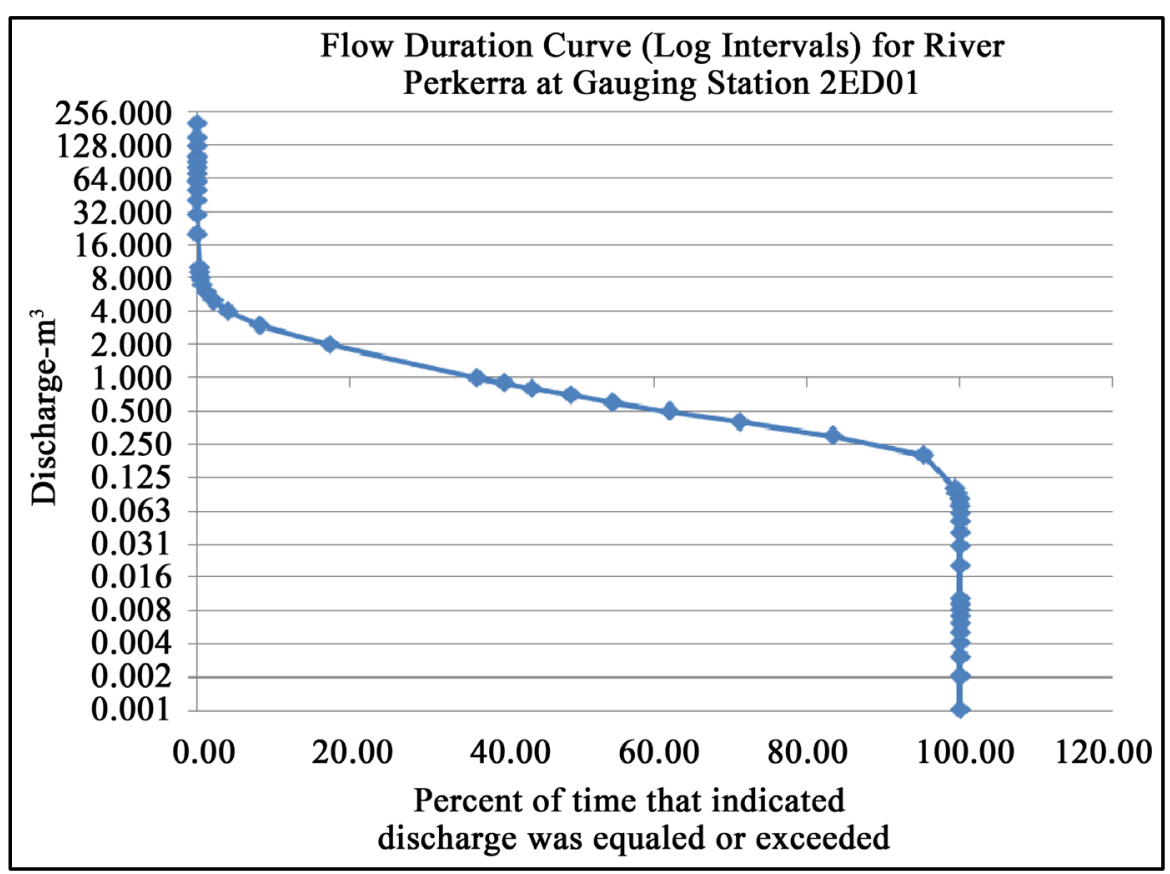

Figure 6. Flow duration curve (log intervals) for River Perkerra at gauging station 2ED01.

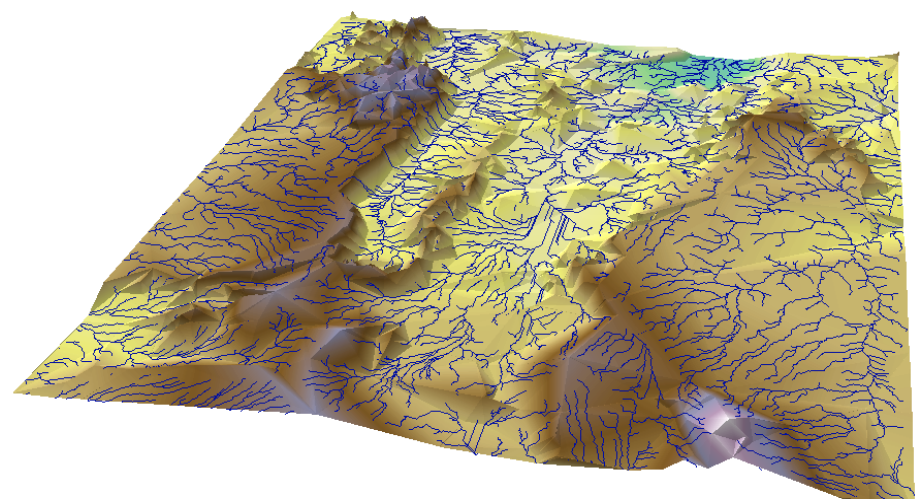

Figure 7. TIN surface 3D rendering using ArcScene.

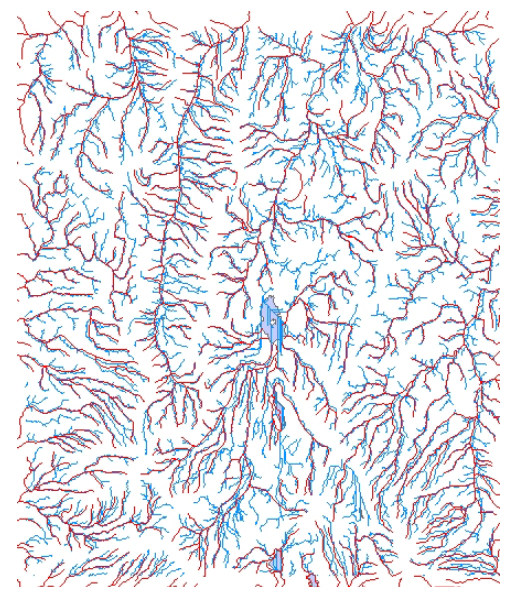

Figure 8. Comparison between derived stream network (blue) and that digitized from topographic maps (red). 


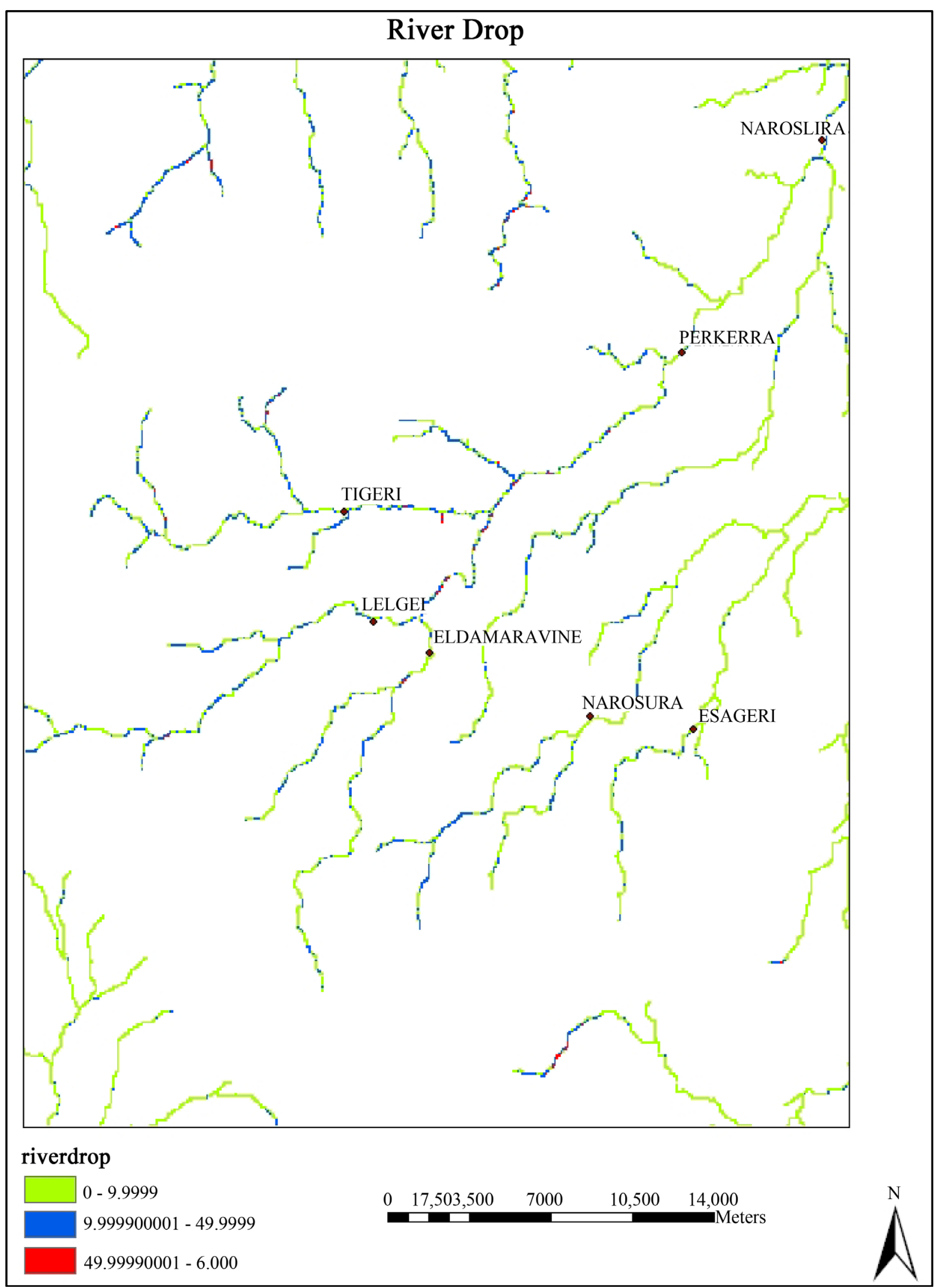

Figure 9. Close up image of river drop points by head classification. 
respect to the derived stream network.

\subsection{Hydropower Model and Identified Potential Micro Hydropower Sites}

River drop points were extracted from the DEM and stream net-work in order to identify sites along delineated stream network that potentially have suitable head requirement for locating micro hydropower plants. Figure 9 shows a close up view of one of the stream segments and drop points classified by available head.

The extractable Q40, Q50 \& Q60 hydropower output potential for sites along the Tigeri, Lelgel and Eldama Ravine gauged sections of the River Perkerra identified to have a head drop of 50 metres and above are tabulated on Table 2.

\section{Conclusions and Further Work}

This research demonstrated the use of GIS in accurately identifying and assessing the extent of hydropower

Table 2. Potential hydropower output sites with $50 \mathrm{~m}$ or more head.

\begin{tabular}{|c|c|c|c|c|c|c|c|c|}
\hline \multirow[t]{2}{*}{ Reference Gauging Point (s) } & \multirow{2}{*}{$\begin{array}{l}\text { Head } \\
\text { Drop } \\
(\mathbf{m})\end{array}$} & \multirow{2}{*}{$\begin{array}{c}\text { Hydro Site } \\
\text { Coordinates } \\
\text { (Decimal Degrees) }\end{array}$} & \multicolumn{3}{|c|}{$\begin{array}{l}\text { Total Available Discharge } \\
\qquad\left(\mathrm{m}^{3} \cdot \mathrm{s}^{-1}\right)\end{array}$} & \multicolumn{3}{|c|}{$\begin{array}{l}\text { Total Potential Power } \\
\text { Output (MW) }\end{array}$} \\
\hline & & & Q40 & Q50 & Q60 & Q40 & Q50 & Q60 \\
\hline TIGERI 2ED01 & 51 & $35.712236,0.102368$ & 0.82 & 0.80 & 0.80 & 0.410 & 0.400 & 0.400 \\
\hline ELDAMA RAVINE 2ED03 & 52 & $35.711548,0.035348$ & 0.30 & 0.28 & 0.24 & 0.153 & 0.143 & 0.122 \\
\hline ELDAMA RAVINE 2ED03 & 50 & $35.712513,0.036192$ & 0.30 & 0.28 & 0.24 & 0.147 & 0.137 & 0.118 \\
\hline $\begin{array}{c}\text { LELGEL 2ED02 \& } \\
\text { ELDAMA RAVINE 2ED03 }\end{array}$ & 58 & $35.725049,0.069461$ & 0.65 & 0.58 & 0.52 & 0.370 & 0.330 & 0.296 \\
\hline $\begin{array}{c}\text { LELGEL 2ED02 \& } \\
\text { ELDAMA RAVINE 2ED03 }\end{array}$ & 63 & $35.725772,0.069943$ & 0.65 & 0.58 & 0.52 & 0.402 & 0.358 & 0.321 \\
\hline $\begin{array}{c}\text { LELGEL 2ED02 \& } \\
\text { ELDAMA RAVINE 2ED03 }\end{array}$ & 55 & $35.726978,0.071630$ & 0.65 & 0.58 & 0.52 & 0.351 & 0.313 & 0.281 \\
\hline $\begin{array}{c}\text { LELGEL 2ED02 \& } \\
\text { ELDAMA RAVINE 2ED03 }\end{array}$ & 62 & $35.728304,0.074523$ & 0.65 & 0.58 & 0.52 & 0.395 & 0.353 & 0.316 \\
\hline $\begin{array}{c}\text { LELGEL 2ED02 \& } \\
\text { ELDAMA RAVINE 2ED03 }\end{array}$ & 51 & $35.729388,0.075126$ & 0.65 & 0.58 & 0.52 & 0.325 & 0.290 & 0.260 \\
\hline $\begin{array}{c}\text { LELGEL 2ED02 \& } \\
\text { ELDAMA RAVINE 2ED03 }\end{array}$ & 58 & $35.739343,0.086141$ & 0.65 & 0.58 & 0.52 & 0.370 & 0.330 & 0.296 \\
\hline $\begin{array}{c}\text { LELGEL 2ED02 \& } \\
\text { ELDAMA RAVINE 2ED03 }\end{array}$ & 78 & $35.742660,0.092853$ & 0.65 & 0.58 & 0.52 & 0.497 & 0.444 & 0.398 \\
\hline $\begin{array}{c}\text { LELGEL 2ED02 \& } \\
\text { ELDAMA RAVINE 2ED03 }\end{array}$ & 69 & $35.743586,0.093778$ & 0.65 & 0.58 & 0.52 & 0.440 & 0.393 & 0.352 \\
\hline $\begin{array}{c}\text { LELGEL 2ED02 \& } \\
\text { ELDAMA RAVINE 2ED03 }\end{array}$ & 79 & $35.744357,0.094704$ & 0.65 & 0.58 & 0.52 & 0.504 & 0.449 & 0.403 \\
\hline $\begin{array}{c}\text { LELGEL 2ED02 \& } \\
\text { ELDAMA RAVINE 2ED03 }\end{array}$ & 85 & $35.746131,0.099024$ & 0.65 & 0.58 & 0.52 & 0.542 & 0.484 & 0.434 \\
\hline $\begin{array}{l}\text { TIGERI 2ED01 \& LELGEL } \\
\text { 2ED02 \& ELDAMA RAVINE } \\
\text { 2ED03 }\end{array}$ & 73 & $35.748615,0.103190$ & 1.47 & 1.38 & 1.32 & 1.053 & 0.988 & 0.945 \\
\hline $\begin{array}{l}\text { TIGERI 2ED01 \& LELGEL } \\
\text { 2ED02 \& ELDAMA RAVINE } \\
\text { 2ED03 }\end{array}$ & 67 & $35.754556,0.110750$ & 1.47 & 1.38 & 1.32 & 0.966 & 0.907 & 0.868 \\
\hline $\begin{array}{l}\text { TIGERI 2ED01 \& LELGEL } \\
\text { 2ED02 \& ELDAMA RAVINE } \\
\text { 2ED03 }\end{array}$ & 62 & $35.755250,0.111599$ & 1.47 & 1.38 & 1.32 & 0.894 & 0.839 & 0.803 \\
\hline $\begin{array}{l}\text { TIGERI 2ED01 \& LELGEL } \\
\text { 2ED02 \& ELDAMA RAVINE } \\
\text { 2ED03 }\end{array}$ & 55 & $35.756253,0.112370$ & 1.47 & 1.38 & 1.32 & 0.793 & 0.745 & 0.712 \\
\hline
\end{tabular}


resources, including whether the availability of sites with micro hydropower potential within the study area was sufficiently large to warrant further development.

Based on the results it is established that:

1) GIS can be used to accurately identify sites at discrete geographic locations along any stream drainage network.

2) Potential sites for hydropower development are numerous within the study area and can reliably generate electricity all year round. These sites have hydropower potential characteristic of pico, micro, mini and small hydropower installations.

The use of GIS in identification and assessment of a country's hydropower potential should be adopted. With sufficient data on catchment discharge, the model can be further enhanced to obtain the total micro hydropower potential of River Perkerra whereby the potentials of every stream segment are aggregated. This research can be replicated to assess hydropower potential for any river network

\section{References}

[1] GoK (2007) Vision 2030. Government of the Republic of Kenya, Ministry of Planning and National Development and the National Economic and Social Council (NESC), Office of the President, Nairobi.

[2] Arrhenius, S. (1896) XXXI. On the Influence of Carbonic Acid in the Air upon the Temperature of the Ground. The London, Edinburgh, and Dublin Philosophical Magazine and Journal of Science, 41, 237-276. http://dx.doi.org/10.1080/14786449608620846

[3] Mirza, M.M.Q. (2003) Climate Change and Extreme Weather Events: Can Developing Countries Adapt? Climate Policy, 3, 233-248.

[4] Kabat, P., Schulze, R., Hellmuth, M. andVeraart, J. (2003) Coping with Impacts of Climate Variability and Climate Change in Water Management: A Scoping Paper. DWC-Report No. DWCSSO-01 Dialogue on Water and Climate, Wageningen.

[5] Bergkamp, G., Orlando, B. and Burton, I. (2003) Change: Adaptation of Water Resources Management to Climate Change. IUCN, Gland.

[6] Houghton, J.T., Albritton, D., Meira Filho, L., Cubasch, U., Dai, X., Ding, Y., et al. (2001) Technical Summary of Working Group 1. In: Houghton, J.T., Ding, Y., Griggs, D.J., Noguer, M., van der Linden, P.J., Dai, X., Maskell, K. and Johnson, C.A., Eds., Climate Change 2001: The Scientific Basis. Contributions of Working Group I to the Third Assessment Report of the Intergovernmental Panel on Climate Change, Cambridge University Press, Cambridge, 3-45.

[7] Cheng, B.S. (1995) An Investigation of Cointegration and Causality between Energy Consumption and Economic Growth. Journal of Energy and Development, 21, .

[8] Pacala, S. and Socolow, R. (2004) Stabilization Wedges: Solving the Climate Problem for the Next 50 Years with Current Technologies. Science, 305, 968-972. http://dx.doi.org/10.1126/science.1100103

[9] Frey, G.W. and Linke, D.M. (2002) Hydropower as a Renewable and Sustainable Energy Resource Meeting Global Energy Challenges in a Reasonable Way. Energy Policy, 30, 1261-1265. http://dx.doi.org/10.1016/S0301-4215(02)00086-1

[10] GoK (2004) Sessional Paper No. 4 of 2004 on Energy. National Energy Policy Ed., Nairobi.

[11] Spain, S.D. (2011) Hydro Power Generation: Global and US Perspective. In: Rao, K.R., Ed., Energy and Power Generation Handbook, Chapter 11, ASME Press, New York.

[12] Yannopoulos, S., Lyberatos, G., Angelakis, A. and Theodossiou, N. (2014) Water Pumps through the Ages. e-Proceedings of IWA Regional Symposium on Water, Wastewater and Environment: Traditions and Culture, Hellenic Open Univ., Patras, 615-626.

[13] Reynolds, T.S. (2002) Stronger than a Hundred Men: A History of the Vertical Water Wheel. JHU Press, Baltimore.

[14] Fraenkel, P., Paish, O., Bokalders, V. and Harvey, A. (1991) Micro-Hydro Power-A Guide For development Work. Russell Press Ltd., Nottingham. http://dx.doi.org/10.3362/9781780442815

[15] Klunne, W.J. and Michael, E.G. (2010) Increasing Sustainability of Rural Community Electricity Schemes-Case Study of Small Hydropower in Tanzania. International Journal of Low-Carbon Technologies, 5, 144-147. http://dx.doi.org/10.1093/ijlct/ctq019

[16] Mirza, U.K., Ahmad, N., Majeed, T. and Harijan, K. (2008) Hydropower Use in Pakistan: Past, Present and Future. Renewable and Sustainable Energy Reviews, 12, 1641-1651. http://dx.doi.org/10.1016/j.rser.2007.01.028

[17] Evans, A., Strezov, V. and Evans, T.J. (2009) Assessment of Sustainability Indicators for Renewable Energy Technologies. Renewable and Sustainable Energy Reviews, 13, 1082-1088. http://dx.doi.org/10.1016/j.rser.2008.03.008 
[18] Renöfält, B., Jansson, R. and Nilsson, C. (2010) Effects of Hydropower Generation and Opportunities for Environmental Flow Management in Swedish Riverine Ecosystems. Freshwater Biology, 55, 49-67. http://dx.doi.org/10.1111/j.1365-2427.2009.02241.x

[19] Paish, O. (2002) Micro-Hydropower: Status and Prospects. Journal of Power and Energy, 216, 31-40. http://dx.doi.org/10.1243/095765002760024827

[20] Pepermans, G., Driesen, J., Haeseldonckx, D., Belmans, R. and D’haeseleer, W. (2005) Distributed Generation: Definition, Benefits and Issues. Energy Policy, 33, 787-798. http://dx.doi.org/10.1016/j.enpol.2003.10.004

[21] Popli, K. (2012) Barriers in Small Hydro Power Development in India. IASH Journal: International Association for Small Hydro, 1, 3-7.

[22] Rojanamon, P., Chaisomphob, T. and Bureekul, T. (2009) Application of Geographical Information System to Site Selection of Small Run-of-River Hydropower Project by Considering Engineering/Economic/Environmental Criteria and Social Impact. Renewable and Sustainable Energy Reviews, 13, 2336-2348. http://dx.doi.org/10.1016/j.rser.2009.07.003

[23] Das, S. and Paul, P. (2006) Selection of Site for Small Hydel Using GIS in the Himalayan Region of India. Journal of Spatial Hydrology, 6, 18-28.

[24] Jha, R. (2010) Total Run-of-River Type Hydropower Potential of Nepal. Hydro Nepal: Journal of Water, Energy and Environment, 7, 8-13.

[25] Feizizadeh, B. and Haslauer, E.M. (2012) GIS-Based Procedures of Hydropower Potential for Tabriz Basin, Iran. International Journal, 495-502.

\section{Submit or recommend next manuscript to SCIRP and we will provide best service for you:}

Accepting pre-submission inquiries through Email, Facebook, LinkedIn, Twitter, etc.

A wide selection of journals (inclusive of 9 subjects, more than 200 journals)

Providing 24-hour high-quality service

User-friendly online submission system

Fair and swift peer-review system

Efficient typesetting and proofreading procedure

Display of the result of downloads and visits, as well as the number of cited articles

Maximum dissemination of your research work

Submit your manuscript at: http://papersubmission.scirp.org/ 